Article

\title{
Green Roofs and Walls Design Intended to Mitigate Climate Change in Urban Areas across All Continents
}

\author{
Fernando Barriuso and Beatriz Urbano *(D) \\ Department of Agricultural and Forestry Engineering, University of Valladolid, 34004 Palencia, Spain; \\ f.barriuso.c@gmail.com \\ * Correspondence: beatriz.urbano@uva.es; Tel.: +34-979-108-469
}

Citation: Barriuso, F.; Urbano, B. Green Roofs and Walls Design Intended to Mitigate Climate Change in Urban Areas across All Continents. Sustainability 2021, 13, 2245. https:// doi.org/10.3390/su13042245

Academic Editor: Nyuk Hien Wong

Received: 18 December 2020

Accepted: 16 February 2021

Published: 19 February 2021

Publisher's Note: MDPI stays neutral with regard to jurisdictional claims in published maps and institutional affiliations.

Copyright: (c) 2021 by the authors. Licensee MDPI, Basel, Switzerland. This article is an open access article distributed under the terms and conditions of the Creative Commons Attribution (CC BY) license (https:// creativecommons.org/licenses/by/ $4.0 /)$.

\begin{abstract}
Green roofs and walls can mitigate the environmental and climate change of a city. They can decrease the urban heat island (UHI), reduce greenhouse gas emissions, fix environmental pollutants, manage urban stormwater runoff, attenuate noise, and enhance biodiversity. This paper aims to analyse green roofs and walls in the possible mitigation of urban climate change and compare it by continent. Green roofs and walls might decrease the air temperature in a city up to $11.3^{\circ} \mathrm{C}$ and lower the thermal transmittance into buildings up to $0.27 \mathrm{~W} / \mathrm{m}^{2} \mathrm{~K}$. Urban greening might sequester up to $375 \mathrm{~g} \mathrm{C} \cdot \mathrm{m}^{-2}$ per two growing seasons and increase stormwater retention up to $100 \%$. Urban greening might attenuate city noise up to $9.5 \mathrm{~dB}$. The results found green roofs and walls of varied effectiveness in ameliorating climate extremes present in host continents. Results show urban planners might focus on green roofs and walls exposure to attenuate temperatures in hotter Asian cities and advise greening in cities in Africa and Asia. European and American designers might optimise runoff water capacity of green roofs and walls systems and use greening in old buildings to improve insulation. Recommendations are made based on the study to concentrate certain designs to have greater impact on priority climate challenges, whether UHI or stormwater related. This study provides information for decision and policymakers regarding design and exposure of green roofs and walls to mitigate urban environmental and climate change.
\end{abstract}

Keywords: green roofs and walls benefits; intercontinental comparison; exposure and design decisions; significance analysis

\section{Introduction}

Green roofs and walls (GRWs) are highly recommended to improve the environment in cities and mitigate climate change. GRWs can modify the city ecosystem. It has been proved that GRWs mitigate the urban heat island (UHI) effect [1], reduce the greenhouse gas emissions [2], attenuate the environmental pollutants [3,4], manage urban stormwater runoff [5], reduce noise [6], and enhance biodiversity [7]. Urban surfaces which are not used, such as building walls, roofs, and open spaces, could be covered with vegetation to mitigate the urban environmental and climate change of the city.

However, the environmental performance of GRWs largely varies with their design [8], for example, slope, vegetation intensity, coverage, etc., and with exposure [9], for example, location, owner, year of construction, etc. Exposure and design studies are necessary to implement environmentally efficient GRWs [8-10]. The previous findings encourage researchers to concentrate on the assessment of environmental benefits due to exposure and design of GRWs $[8,10]$. Information on design and exposure can help urban planners and politicians to implement policies on the local level that will help provide GRW solutions to mitigate urban environmental and climate change.

The research question is: What are the best practices implemented and how effective are they in mitigating local climate extremes in continents across the world? 
This paper aim is two-fold, to revise the potential mitigation of urban climate change according to GRW exposure and design and to provide planning perspectives for GRW development by continent.

The paper is structured as follows: in the second part, the exposure and design of GRWs to mitigate urban environment and climate change are revised; in the third part, mitigation values are estimated for design and exposure of 1727 GRWs worldwide; and fourth, mitigation values are compared between continents in order to provide recommendations based on certain designs and exposure to have greater impact on priority climate challenges. Finally, conclusions, practical implications, limitations, and recommendations are presented.

\section{Green Roofs and Walls Effects}

\subsection{GRW in Urban Heat Island (UHI) Decrease}

Solar radiation, temperature, and winds slow down as they pass through vegetation covering GRW surfaces $[1,11]$. Therefore, the heat exchange between vegetation and air are lower in greening systems than those between constructions and air. Vegetation reduces, in proportion to its density, the wind intensity that is the main factor of UHI $[12,13]$. Vegetation height is important in reducing temperature [11], as well as the type of substrate, composition, depth, and moisture $[14,15]$. The authors demonstrated that $16 \mathrm{~cm}$ of depth of the substrate can reduce the temperature by $7^{\circ} \mathrm{C}$. Moreover, the type of vegetation is crucial [16]. Additionally, the vegetation retains moisture, increasing the relative humidity of city air due to the return of rainwater to its natural cycle [12,17,18]. Köhler and Kaiser [19] demonstrated that an extensive green roof has a stabilisation effect of UHI of $1.5 \mathrm{~K}$ in 20 years.

On the one hand, it has been demonstrated that when both walls and roofs are covered with vegetation, the air temperature decreases the most. When only walls are covered with vegetation, air masses enter heated by plain roofs, especially with the summer isolation, and temperature decreases the least. Along this line, for instance, Alexandri and Jones [20] demonstrated the highest decrease in the air temperature for a walls and roof green system case in Riyadh $\left(11.3^{\circ} \mathrm{C}\right.$ maximum and $9.1^{\circ} \mathrm{C}$ daytime average) compared with a green wall case $\left(5.1^{\circ} \mathrm{C}\right.$ maximum and $3.4^{\circ} \mathrm{C}$ daytime average). In Hong Kong, authors demonstrated a maximum temperature decrease of $8.4^{\circ} \mathrm{C}$ with vertical greenery systems. In Mumbai, which is much more humid, smaller decreases were observed, $6.6^{\circ} \mathrm{C}$ daytime average and $8.0^{\circ} \mathrm{C}$ maximum for the all-green case and 2.7 and $4.4^{\circ} \mathrm{C}$, respectively, for the green wall case. In Moscow, temperature decreased $3.6^{\circ} \mathrm{C}$ maximum and $3.0^{\circ} \mathrm{C}$ daytime average for the all-green case, and 2.6 and $1.7^{\circ} \mathrm{C}$, respectively, for the green wall case. In Singapore, Wong et al. [15] demonstrated a reduction of up to $3.3^{\circ} \mathrm{C}$ using vertical greenery, while Qin et al. [5] showed green roof air temperature decrease of $0.5^{\circ} \mathrm{C}$. In Africa, a temperature reduction of $2.6^{\circ} \mathrm{C}$ was observed using greened panels of vines [21]. Varvara et al. [22] proved temperature decreased $4.5^{\circ} \mathrm{C}$ in summer in Neubrandenburg (Germany). Alonso et al. [23] proved an urban temperature amelioration of $5.0-7.0^{\circ} \mathrm{C}$ in a green roof in Spain. Bass et al. [24] found a temperature reduction up to $10.0^{\circ} \mathrm{C}$ in Toronto using ENVI-met, a high-resolution meteorological simulation model for urban areas that simulates air flow around buildings, surface-atmosphere interactions and turbulence, while Susca et al. [25] demonstrated an average of $2.0^{\circ} \mathrm{C}$ difference in temperatures between the most and least vegetated areas in New York using climatological models. The hotter and drier the climate, the more important the effect of green walls and green roofs on mitigating urban temperatures is. In sum, vegetation can mitigate increased temperatures and bring temperatures down especially for hot climates [26].

On the other hand, Alexandri and Jones [20] pointed out that the vegetation extension, leaf area index [14], and geometry are more important than the orientation of the surface [15] in urban city temperature reduction. For instance, a 70\% coverage ratio and $2.25 \mathrm{~mm}$ total leaf depth could lead to an $80 \%$ temperature reduction [27]. The wider the canyon, the least the temperature decreases with urban greening, although in dense 
cities, overshadow can compromise vegetation development, especially during winter and spring, and multistorey buildings and narrow streets reduce the wind circulation and inhibit temperature reduction [25].

Furthermore, air conditioners discharge heat to the outside. This process raises the surrounding temperature, increasing the UHI [28]. In this sense, GRW improves the building insulation and can decrease the use of air-cooling systems and reduce UHI [29]. Each $4 \mathrm{~cm}$ of GRW vegetation and substrate is comparable to $1 \mathrm{~cm}$ of conventional thermal insulation [30]. Therefore, the insulation materials are crucial in the reduction of the use of air conditioners [31] and city UHI control. Castleton et al. [7] showed that in the UK, no insulation regulation existed before 1965, while from 1965 to 1976, the building regulations defined a maximum roof insulation U-value of $1.42 \mathrm{~W} / \mathrm{m}^{2} \mathrm{~K}$. Moreover, the EU 2010 directive [32] established nearly zero-energy public buildings forcing some buildings and owners to better insulate and reduce the use of air conditioners [28] since 2010.

\subsection{Greenhouse Effect Reduction}

Buildings account for half of the primary energy consumption and, hence, $\mathrm{CO}_{2}$ emissions in developed countries [11,33]. GRWs absorb carbon dioxide and can reduce the greenhouse effect [25,34] by providing oxygen in the urban cores [23]. Along this line, Getter et al. [35] showed that sequestered aboveground carbon varies by type of vegetation and species, ranging from $64 \mathrm{~g} \mathrm{C} \cdot \mathrm{m}^{-2}$ (Sedum acre) to $239 \mathrm{~g} \mathrm{C} \cdot \mathrm{m}^{-2}$ (Sedum album) per two growing seasons, with an average of $168 \mathrm{~g} \mathrm{C} \cdot \mathrm{m}^{-2}$. The total extensive GRW system sequestered $375 \mathrm{~g} \mathrm{C} \cdot \mathrm{m}^{-2}$, mainly by the vegetation and substrate. They demonstrated that greenhouse effect reduction depends on the type of vegetation and the extension greened.

Moreover, GRWs intercept ultraviolet radiation and prevent its direct impact in the city surfaces. The vegetation absorbs solar radiation through several natural processes $[23,36]$. Castleton et al. [7] demonstrated that, from the solar radiation that impacts a vegetated surface, $27 \%$ is reflected, $60 \%$ is absorbed by the plants and the substrate, and $13 \%$ is transmitted into the substrate. Solar radiation impact in the surfaces depends on their orientation, inclination and shading pattern [37].

Moreover, the surface albedo influences the impact of solar radiation, especially during the warm season, and affects air quality and greenhouse gas concentration $[3,25]$. The increase in surface albedo by one square meter of GRW eliminates approximately $38.0 \mathrm{~kg}$ of $\mathrm{CO}_{2}$ eq [25]. The influence of greening is enhanced by $3 \%$ in summer with the increase of the substrate depth, soil relative density [38], and lighter colours [15,39,40]. Moreover, the moisture increases the amount of $\mathrm{CO}_{2}$ eq avoided [11] through additional evapotranspiration $[38,41,42]$.

\subsection{Pollutant Fixation}

GRWs decrease environmental pollution through the fixation of pollutants by the vegetation and substrate [43,44]. It is demonstrated how GRW leachate losses can contribute to nitrogen, carbon and phosphorous in urban areas due to runoff. Vijayaraghavan et al. [44] showed that some of the important components present in runoff include $\mathrm{Na}, \mathrm{K}, \mathrm{Ca}, \mathrm{Mg}$, $\mathrm{Li}, \mathrm{Fe}, \mathrm{Al}, \mathrm{Cu}, \mathrm{NO}_{3} \mathrm{PO}_{4}{ }^{3-}$, and $\mathrm{SO}_{4}{ }^{2-}$ and that the concentrations of most of the chemical components in runoff were highest during the beginning of rain events. However, the concentration of these chemical components in runoff strongly depends on the nature of the substrates and the volume of rain. Alsup et al. [43] demonstrated that the presence of a Sedum hybridum plant decreased the leaching of $\mathrm{Pb}$ over time, and that the leaching of $\mathrm{Cd}$ was generally enhanced by vegetation for most substrates over time. An analysis of the runoff quality of an intensive green roof from Japan and an extensive from Sweden showed that both are a sink for nitrate nitrogen and ammonium nitrogen with similar performance [45]. An intensive green roof is also a sink for total nitrogen in contrast to the extensive roof. Phosphorus release was observed from an extensive green roof, but not from the intensive green roof. 


\subsection{Stormwater Runoff Management}

Urban areas generate considerably more stormwater runoff than natural areas of the same size due to the city impervious structures that impede water infiltration [46,47]. In this sense, GRWs are effective in holding water and slowing water release [47]. Nevertheless, researchers have pointed out the need to consider the urban climate exposure in the management of urban stormwater runoff by GRW systems [45]. In this sense, the mean of the stormwater retention of tropical regions is $65.9 \%$, and in arid climates $71.3 \%$, which are relatively higher than those of warm temperate climates $60.2 \%$ and continental climates $56.0 \%$ [9]. Mentens et al. [48] pointed out a 54.0\% runoff reduction in an extensive green roof in Belgium. Moreover, a longer antecedent dry weather period allows the substrate to dry out through evapotranspiration [49] and, thus, to have more capacity to accept and retain rainwater during the next rainfall event in proportion to rainfall characteristics and intensity $[45,50]$.

Both the hydrologic behaviour and water quality performance of green structures are also dependent on their design [9]. The GRW substrate allows absorption of rainfall, often resulting in an improvement in water runoff management [10]. Several studies argued that substrate depth is a dominant factor in the stormwater retention of greening [8,47,48,51]. Green roofs could lead to $60 \%$ runoff mitigation for extensive green roofs and up to $100 \%$ for intensive green roofs [52]. Vanwoert et al. [47] demonstrated stormwater retention of $82.8 \%$ for a semi-intensive green roof. Mickovski et al. [53] compared the effects of green roofs with respect to surface runoff for three types of vegetation, long grass, short grass, and sedum and determined that sedum had the lowest impact on surface runoff volume. The surface slope is related with the level of potential runoff retention [54], as the percolation process is dominant [9]. Additionally, substrate composition determines the water storage capacity and the hydraulic conductivity of the greening systems [49].

\subsection{Noise Attenuation}

GRW effectively contribute to noise reduction. According to Rudolf [55], a $3.0 \mathrm{~dB}$ decrease in noise is equivalent to a $50 \%$ reduction in the discomfort caused by traffic. Additionally, the European Commission [56] demonstrated the potential of green tops for attenuating noise, with the ability to reduce noise by up to $7.5 \mathrm{~dB}$. Van Renterghem et al. [57], concerned with traffic noise propagation towards the traffic free sides of inner city buildings, showed that GRWs have the highest potential to enhance quietness in the inner city buildings [6]. Proper combinations of roof shape and greening structure have been identified. Green façades are most efficient when applied to narrow city canyons with otherwise acoustically hard façade materials. Yang [58] demonstrated that underground garages reduces car noise by up to $4.0 \mathrm{~dB}(\mathrm{~A})$ and low-growing vegetation can be an effective measure for scattering sound energy, especially at high frequencies. Speech levels and reverberation time at $500 \mathrm{~Hz}$ can decrease by $9.3 \mathrm{~dB}$ and $81 \%$, respectively. The extra sound pressure level attenuation caused by green roof systems could be up to $9.5 \mathrm{~dB}$ at certain frequencies. In outdoor spaces, reverberation time is generally rather long, over $4 \mathrm{~s}$ at $500 \mathrm{~Hz}$, and is influenced by openness, source-receiver distance, and building height. It was also demonstrated that vegetation can be effective in reducing reverberation time by $0.95 \mathrm{~s}$ with a $46 \%$ decrease [58].

\subsection{Biodiversity Increase}

GRWs increase biodiversity using native flora and fauna species depending on the intensity of the greening structures [2,59] (Table 1). Moreover, GRWs are used for provision of nesting areas for species, food production, terrariums, etc. [2]. The spaces for urban greening are retrieved, which positively influences the citizens; additionally, they strengthen food and nutritional security, and help to create greener cities [55]. In this sense, Food and Agriculture Organization [60] promotes "green cities" designed for resilience, self-reliance, and social, economic, and environmental sustainability. For its part, EU 
policy [61] encourages incorporation of urban greening designed and managed to deliver a wide range of ecosystem services.

Table 1. Factors involved in green roofs and walls in climate change mitigation classified by exposure and design and ordered alphabetically, with the most relevant publication to this topic in the brackets.

\begin{tabular}{|c|c|}
\hline Exposure & Design \\
\hline Urban heat island decrease & Urban heat island decrease \\
\hline Building owner [32] & Abundance of vegetation $[12,13,25,39]$ \\
\hline Canyon geometries [20] & Geometry of vegetation $[15]$ \\
\hline City density $[15,20,25,27]$ & Leaf area index $[14,15]$ \\
\hline Cooling/heating needs [29] & Plant height $[25,39]$ \\
\hline Longitude of city $[1,25]$ & Thickness of the layers of the planted part $[11,15,25]$ \\
\hline Relative humidity $[20,26]$ & Type of substrate, composition, and moisture content $[14,15]$ \\
\hline Solar radiation $[11,12]$ & Type of vegetation $[8,15,16,35]$ \\
\hline Temperature [60] & Wall/roof covered [20] \\
\hline \multicolumn{2}{|l|}{ Wind speed $[11,25]$} \\
\hline Greenhouse effect reduction & Greenhouse effect reduction \\
\hline Building insulation $[7,11,33]$ & Albedo $[25,39]$ \\
\hline Insulation regulations [7] & Light colour $[15,39]$ \\
\hline Inclination [20] & Extension greened [35] \\
\hline Orientation [20] & Evapotranspiration [41] \\
\hline Shading patterns [20] & Soil moisture $[41,42]$ \\
\hline Solar/ultraviolet radiation [41] & Soil relative density [38] \\
\hline \multirow[t]{2}{*}{ Year of construction [7] } & Growing media depth $[7,30,40]$ \\
\hline & Type of vegetation $[35,40]$ \\
\hline Pollutants fixation & Pollutants fixation \\
\hline Rain events patterns [44] & Intensive/extensive of greening system [45] \\
\hline \multirow[t]{2}{*}{ Volume of rain [45] } & Nature of substrates [44] \\
\hline & Type of vegetation [43] \\
\hline Runoff water management & Runoff water management \\
\hline Antecedent dry weather period [9] & Growing media composition [49] \\
\hline Climatic exposure $[9,45]$ & Intensive/extensive of greening system $[8,17,47,52]$ \\
\hline Evapotranspiration [9] & Media depth $[10,48]$ \\
\hline Rainfall characteristics [9] & Slope $[45]$ \\
\hline Rainfall intensity $[45,50]$ & Type of vegetation $[5,16,53]$ \\
\hline Noise attenuation & Noise attenuation \\
\hline Building height [58] & Roof shape $[56,57]$ \\
\hline Canyon geometries [57] & Type of vegetation [58] \\
\hline Materials adjacent street [56] & Biodiversity enhancement \\
\hline Noise frequencies [58] & Intensive/extensive of greening system [2] \\
\hline Openness [58] & Native flora and fauna species [2] \\
\hline Source-receiver distance [58] & \\
\hline
\end{tabular}

\section{Mitigation Values}

GRW exposure and design were evaluated in 1727 GRW interventions from Greenroofs.com. Greenroofs.com is a collaborative platform for the GRW industry that shows cases of greening infrastructures. The Table 2 presents the characteristics of the GRW interventions of the sample.

Table 2. Green roofs and walls of the sample characteristics. Relative frequencies in percentage of the qualitative variables and minimum, maximum, and mean \pm standard deviation (SD) of the quantitative variables.

\begin{tabular}{|c|c|c|c|c|c|}
\hline Variable & Cases & Frequency (\%) & Variable & Cases & Freq. (\%) \\
\hline \multirow[t]{5}{*}{ Continent } & America & 82.32 & Intensity & Extensive & 65.08 \\
\hline & Europe & 12.42 & & Intensive & 22.83 \\
\hline & Asia & 4.11 & & Living walls & 6.04 \\
\hline & Oceania & 0.98 & & Semi-intensive & 5.22 \\
\hline & Africa & 0.17 & & Inter. living wall & 0.83 \\
\hline \multirow[t]{3}{*}{ Year greening } & 2000-2009 & 62.90 & Location & Street & 50.23 \\
\hline & 2010-2018 & 32.57 & & Avenue & 24.24 \\
\hline & 1914-1999 & 4.53 & & Park & 14.99 \\
\hline
\end{tabular}


Table 2. Cont.

\begin{tabular}{|c|c|c|c|c|c|}
\hline Variable & Cases & Frequency (\%) & Variable & Cases & Freq. (\%) \\
\hline \multirow[t]{2}{*}{ Building owner } & Private & 69.70 & & Boulevard & 7.09 \\
\hline & Public & 30.30 & & Campus & 3.45 \\
\hline Variable & [Min; Max] & Mean \pm SD & Köppen-Geiger & Climate group $\mathrm{C}(\mathrm{Cfa} ; \mathrm{Cfb})$ & $\begin{array}{c}67.17 \\
(44.82 ; 11.35)\end{array}$ \\
\hline Slope (\%) & {$[0.00 ; 100.00]$} & $10.85 \pm 25.95$ & classification & Climate group D & 25.65 \\
\hline Population & {$[299 ; 24,150,000]$} & $1,474,597 \pm 2,764,572.42$ & & Climate group A & 3.82 \\
\hline Extension $\left(\mathrm{m}^{2}\right)$ & {$[2.00 ; 115,000]$} & $2095.58 \pm 7337.29$ & & Climate group B & 3.36 \\
\hline
\end{tabular}

To compare the mitigation, scales were created using data gathered from the sampling or from the revision. A scale change was performed in order to obtain the same variation range of ten points for each indicator.

\subsection{Exposure Mitigation Values}

The location of the GRW system in a rooftop, facade, boulevard, narrow street, etc. [20] was considered to evaluate its orientation, inclination, and shading pattern within its openness and distance determining the potential UHI decrease [25], greenhouse effect reduction [20], and noise attenuation [58]. Google Maps and photographs of the 1727 GRWs were used to measure location. Points were given according to location. The highest mitigation was proved in all-green interventions and, therefore, an additional point given if both wall and roof were greened.

City population, longitude and density shape the height of buildings and noise frequencies of the city and determine potential UHI decrease $[1,15,27]$ and noise attenuation [58]. Cities in the sample were ranked according to their population. Ten marks were given to the cities in the first decile of the sample, nine points to cities in the second decile, and successively up to the ten-decile cities with 1 point.

The climatic exposure informs about wind speed, temperature, relative humidity, solar radiation, rainfall intensity, and characteristics determining the potential UHI decrease, greenhouse effect reduction, pollutants fixation, and runoff water management. Therefore, the Köppen-Geiger climate groups were used to classify the climatic location of the greening interventions [62]. It categorises climates based on annual and monthly averages of temperature and precipitation, and it classifies the world into five primary climatic groups: A (tropical), B (dry arid and semi-arid), C (temperate with the subgroups Cfa humid subtropical and Cfb oceanic), D (continental), and E (polar).

The GRW temperature attenuation demonstrated by Kottek et al. [61] for the different Köppen-Geiger climate groups was used to assign each intervention a temperature reduction. In the climate group A, the temperature attenuated by GRW has been demonstrated varied from $8.4^{\circ} \mathrm{C}$ in Hong Kong to $0.3^{\circ} \mathrm{C}$ in Singapore with a measure of $3.3^{\circ} \mathrm{C}$ found in a green wall in Singapore. Therefore, the temperature attenuation by GRW in Köppen-Geiger climate group A varies from $0.3^{\circ} \mathrm{C}$ to an average of $5.8^{\circ} \mathrm{C}$. Then, the average temperature attenuation considered was $3.1^{\circ} \mathrm{C}$.

It has been proven that the city temperature attenuation in Köppen-Geiger climate group B cities varied from an average of $9.6^{\circ} \mathrm{C}$ (average of $11.3^{\circ} \mathrm{C}$ for a wall and roof project in Riyadh and $8.0^{\circ} \mathrm{C}$ in Mumbai) to an average of $4.7^{\circ} \mathrm{C}$, from $5.1^{\circ} \mathrm{C}$ of a greened wall in Riyadh to $4.4^{\circ} \mathrm{C}$ of a greened wall project in Mumbai. The average temperature attenuation considered for Köppen-Geiger climate group B was $7.2{ }^{\circ} \mathrm{C}$.

The city temperature attenuation found in the Köppen-Geiger climate group $\mathrm{C}$ cities varied from 5.0 to $7.0^{\circ} \mathrm{C}$ in Spain. An average temperature attenuation of $6.0^{\circ} \mathrm{C}$ was considered in Köppen-Geiger climate group C cities.

The city temperature attenuation in the Köppen-Geiger climate group D cities varied from $2.0{ }^{\circ} \mathrm{C}$ in New York City from a vegetated to non-vegetated area up to $10.0{ }^{\circ} \mathrm{C}$ observed in Toronto, passing through $4.5^{\circ} \mathrm{C}$ in Germany and $2.6{ }^{\circ} \mathrm{C}$ in Moscow. Therefore, an average temperature attenuation of $4.8^{\circ} \mathrm{C}$ was considered in Köppen-Geiger climate group D cities. 
Next, the stormwater retention rate in the Köppen-Geiger climate groups by Akther et al. [9] was used to estimate the stormwater retention of the sample. The medians of the stormwater retention rate of Köppen-Geiger climate group A (73.0\%) and group B (78.1\%) were relatively higher than those of group C $(63.0 \%)$ and group D $(57.1 \%)$. Cfa group $(95.0 \%)$ was significantly higher than that of $\mathrm{Cfb}$ group $(60.2 \%)$.

Insulation materials and regulations, cooling and heating needs, year of construction, and the building owner determine the possible UHI decrease, greenhouse effect reduction, and noise attenuation. Along this line, proper insulation was estimated in EU public buildings after 2010 with 10 points and 8 points for private buildings, fair insulation for buildings from 2000 to 2010 with 6 points in public constructions and 4 points in private buildings. Finally, failed insulation was found for buildings before 1999 with 2 points in both public and private buildings.

\subsection{Design Mitigation Values}

Wong et al. [40] calculated the thermal resistance of each vegetation species and compared the thermal transmittance for intensive and extensive GRW systems. They pointed out a U-value of $0.42 \mathrm{~W} / \mathrm{m}^{2} \mathrm{~K}$ for a roof covered by turf. The turf scenario best represents an extensive roof system. A roof covered by shrubs, which represents a semiintensive system, presented a U-value of $0.27 \mathrm{~W} / \mathrm{m}^{2} \mathrm{~K}$, and a roof covered by trees, which represents an intensive roof, obtained a U-value of $0.34 \mathrm{~W} / \mathrm{m}^{2} \mathrm{~K}$. Semi-intensive GRW projects were given 10 points; interpolating an intensive greening score of 7.1 points and extensive ones of 3.8 points.

The proven stormwater retention of green roofs $[47,51]$ according to the intensity of the greening system was used for scale. It was considered that an extensive green roof could lead to $60 \%$ runoff mitigation (6.0 points on the scale) and an intensive green roof up to $100 \%$ (10 points) [52]. The stormwater retention for a semi-intensive green roof was considered $82.8 \%$ ( 8.3 points).

The greater the coverage of walls and roofs by greening, the larger the UHI decrease, greenhouse effect reduction, runoff water management, noise attenuation, and biodiversity enhancement $[56,57]$. In this sense, the GRWs in the sample were ranked according to the extension covered by vegetation. Ten marks were given to the greening in the first decile of the sample, nine points to the second-decile extension and successively up to the ten-decile greenings with 1 point.

The slope of greening determines the urban stormwater runoff management $[9,45]$. In this sense, a slope of $0 \%$ was considered $100 \%$ stormwater runoff retention capacity (10 points for stormwater runoff retention) and a $100 \%$ slope means $0 \%$ retention ( 0 points for stormwater runoff retention) (Table 3 ).

Table 3. Exposure and design factors values, in the brackets the source from which the values were gathered. A scale change was performed in order to obtain the same variation range for each indicator (see the text for further details).

\begin{tabular}{|c|c|c|c|}
\hline \multicolumn{2}{|c|}{ Exposure } & \multicolumn{2}{|c|}{ Design } \\
\hline Indicators & Marks and Cases & Indicators & Marks and Cases \\
\hline Location [Sampling] & $\begin{array}{l}\text { 10.0: Green roof in a boulevard } \\
\text { 9.0: Green wall in a boulevard } \\
\text { 8.0: Green roof in an avenue } \\
\text { 7.0: Green wall in an avenue } \\
\text { 6.0: Green roof in a park } \\
\text { 5.0: Green wall in a park } \\
\text { 4.0: Green roof in a campus } \\
\text { 3.0: Green wall in a campus } \\
\text { 2.0: Green roof in a street } \\
\text { 1.0: Green wall in a street }\end{array}$ & $\begin{array}{l}\text { Intensive/extensive thermal } \\
\text { transmittance [40] }\end{array}$ & $\begin{array}{c}\text { 10: Semi-intensive/living wall } \\
\text { 7.1: Intensive } \\
\text { 3.8: Extensive } \\
\text { 0.0: Living wall interior }\end{array}$ \\
\hline
\end{tabular}


Table 3. Cont.

\begin{tabular}{|c|c|c|c|}
\hline \multicolumn{2}{|c|}{ Exposure } & \multicolumn{2}{|c|}{ Design } \\
\hline Indicators & Marks and Cases & Indicators & Marks and Cases \\
\hline $\begin{array}{l}\text { Population } \\
\text { [Sampling] }\end{array}$ & $\begin{array}{l}\text { 10.0: } 21.8-24.2 \text { million inhabitants } \\
\text { 9.0: 19.4-21.7 million inhabitants } \\
\text { 8.0: 17.0-19.3 million inhabitants } \\
\text { 7.0: } 14.5-16.9 \text { million inhabitants } \\
\text { 6.0: } 12.1-14.4 \text { million inhabitants } \\
\text { 5.0: } 9.7-12.0 \text { million inhabitants } \\
\text { 4.0: 7.3-9.6 million inhabitants } \\
\text { 3.0: 4.9-7.2 million inhabitants } \\
\text { 2.0: } 2.5-4.8 \text { million inhabitants } \\
\text { 1.0: Up to } 2.4 \text { million inhabitants }\end{array}$ & $\begin{array}{l}\text { Intensive/extensive runoff } \\
\text { water } \\
\text { Management [52] }\end{array}$ & $\begin{array}{l}\text { 10: Intensive } \\
\text { 8.3: Semi-intensive } \\
\text { 6.0: Extensive } \\
\text { 3.0: Living wall } \\
\text { 0.0: Living wall interior }\end{array}$ \\
\hline Climatic exposure UHI [6] & $\begin{array}{l}\text { 3.1: Köppen-Geiger climate group A } \\
\text { 7.2: Köppen-Geiger climate group B } \\
\text { 6.0: Köppen-Geiger climate group C } \\
\text { 4.8: Köppen-Geiger climate group D }\end{array}$ & $\begin{array}{l}\text { Greened } \\
\text { extension } \\
\text { [Sampling] }\end{array}$ & $\begin{array}{c}\text { 10.0: } 103,501-115,003 \text { square metres } \\
\text { 9.0: } 92,001-103,500 \text { square metres } \\
\text { 8.0: } 80,501-92,000 \text { square metres } \\
\text { 7.0: } 69,001-80,500 \text { square metres } \\
\text { 6.0: } 57,501-69,000 \text { square metres } \\
\text { 5.0: } 46,001-57,500 \text { square metres } \\
\text { 4.0: } 34,501-46,000 \text { square metres } \\
\text { 3.0: } 23,001-34,500 \text { square metres } \\
\text { 2.0: } 11,501-23,000 \text { square metre s } \\
\text { 1.0: Up to } 11,500 \text { square metres }\end{array}$ \\
\hline $\begin{array}{l}\text { Climatic exposure } \\
\text { stormwater runoff } \\
\text { management [9] }\end{array}$ & $\begin{array}{l}\text { 7.3: Köppen-Geiger climate group A } \\
\text { 7.8: Köppen-Geiger climate group B } \\
\text { 6.3: Köppen-Geiger climate group C } \\
\text { 9.5: Köppen-Geiger climate group Cfa } \\
\text { 6.3: Köppen-Geiger climate group Cfb } \\
\text { 5.7: Köppen-Geiger climate group D }\end{array}$ & $\begin{array}{c}\text { Slope runoff water } \\
\text { management [Sampling] }\end{array}$ & $\begin{array}{l}\text { 10.0: } 0.1-1 \% \text { slope } \\
\text { 9.0: } 1-10 \% \text { slope } \\
\text { 8.0: } 11-20 \% \text { slope } \\
\text { 7.0: } 21-30 \% \text { slope } \\
\text { 6.0: } 31-40 \% \text { slope } \\
\text { 5.0: } 41-50 \% \text { slope } \\
\text { 4.0: } 51-60 \% \text { slope } \\
\text { 3.0: } 61-70 \% \text { slope } \\
\text { 2.0: } 71-80 \% \text { slope } \\
\text { 1.0: } 81-90 \% \text { slope } \\
\text { 0.0: } 91-100 \% \text { slope }\end{array}$ \\
\hline Year and owner [Sampling] & $\begin{array}{l}\text { 10.0: After } 2010 \text { public building } \\
\text { 8.0: After } 2010 \text { private building } \\
\text { 6.0: 2009-2000 public buildings } \\
\text { 4.0: 2009-2000 private buildings } \\
\text { 2.0: Before } 2000\end{array}$ & & \\
\hline
\end{tabular}

\subsection{Data Analysis}

Analysis of variance (ANOVA) was used to compare the variation of the total scores of the GRW interventions between continents against the variation within groups. Statistically significant differences between means were determined ( $\mathrm{F}$ and $p$-value). The significance $(p<0.05)$ was obtained using Levene's test. Following that, Fisher's least significant difference post hoc test was used to explore all possible pairwise means of the continent comparisons to identify which pair of continents was statistically different.

\section{Results and Discussion}

\subsection{Comparison of Greening Exposure by Continent}

Findings show a good practice when both walls and roofs are designed covered of vegetation where air temperature can decrease up to $11.3^{\circ} \mathrm{C}$ [20]. Extensive, intensive, and GRWs with low slope reduce the greenhouse effect, with up to $375 \mathrm{~g} \mathrm{C} \cdot \mathrm{m}^{-2}$ sequestered [35] and retained stormwater up to 100\% [52]. GRWs located in tropical regions and arid climates retain greater stormwater, up to 71.3\% [9]. GRWs situated in semi-open areas, because narrow streets and multistorey buildings reduce the wind circulation and inhibit city temperature reduction and UHI [25]. GRW in old, private buildings decrease the use of air-cooling systems and reduce UHI because each $4 \mathrm{~cm}$ of vegetation and substrate is comparable to $1 \mathrm{~cm}$ of conventional thermal insulation [30]. GRW located in highly populated cities attenuate city noise the most, up to $9.5 \mathrm{~dB}$ [58]. 
A large number of GRWs located in open spaces and academic campuses were found far from dense city cores with a limited mitigation of UHI and urban noise. This result aims to plan GRW in the interconnected spaces within cities in order to more efficiently attenuate UHI [25] and/or in narrow streets to better reduce urban noise [58]. Greening locations in Oceania had the lowest attenuation of city temperatures and differed from those in America, Europe, and Asia. GRWs in America and Asia are more likely located in semi-open areas, increasing the wind circulation and reducing the city temperature and UHI [25]. Designers should focus on temperature attenuation and noise reduction possibilities of GRW in cities in favour of wind circulation and reducing UHI.

GRW structures were mostly found in small cities with an average of 2.1 million inhabitants in comparison with the most populated cities of the world [62]. Therefore, decision makers should focus on greening extended, highly populated cities with high buildings and more noise that need to reduce temperature and UHI the most $[1,15,27]$ and attenuate noise [58]. Most of the greenings were found in America and Europe. Asia differed significantly from the other continents with the greening of the largest cities. The fastest growing cities are located in low-income countries of Asia and Africa while the main GRWs are located in America and Europe. During the next 10 years, the inhabitants in sub-Saharan Africa are expected to grow by $45 \%$, from 320 million to 460 million. By 2025, the urban population of the least developed countries in Asia is expected will grow from 90 million to 150 million [62]. This result encourages the development of GRW in expected growing cities located in the African and Asian continents.

According to this line, GRW was mainly located in two climatic groups, group C temperate and group D continental, while only a few interventions were found in group A tropical and group $\mathrm{B}$ arid. This result is in consonance with the level of development of the countries in group C and group D [9]. This result has sense because the cost of the GRW might inhibit its installation in poor countries. Moreover, developed countries, for example, Germany, the United States of America, and Canada, are strongly promoting GRW [9]. A report shows [63] that 721.8 hectares of flat roofs of Germany are covered by vegetation. Living Roofs [64] pointed out that in the Greater London area exists 17.5 hectares of green roofs.

This result advises policymakers in group A tropical and group B arid regions to install GRW which might control and improve stormwater retention, with a better retention to up to the $15.3 \%$ [9] than in temperate and continental climates. European greening presented the least stormwater retention, similar to Oceania, but significantly different from the other continents. African interventions presented higher stormwater retention explained by lower rainfall intensity and larger retention [50]. These results challenge urban planners to locate greening in climate group areas of Europe and Oceania in order to better manage stormwater runoff.

The concentration of GRWs in temperate and continental climates encourages planners and policymakers to green new areas in Asian cities, which represent the lowest UHI decrease and significantly differ from the rest of the continents. These results agree with Alexandri and Jones [20] that the hotter and drier a climate, the more important the effect of GRW on mitigating urban temperatures. Vegetation can mitigate temperatures especially for hot climates [26].

The oldest, least insulated private buildings greened were in Europe and significantly differed from the rest of the continents [64]. This result encourages planners to considerate of greening in Europe for building insulation, decrease the use of air-cooling systems, and reduce UHI [29].

\subsection{Greening Design Comparison}

The lowest thermal transmittance and best insulation due to the intensity of the GRW systems were found in Asia. Conversely, America and Europe showed less energy consumption reduction due to greening intensity. This result is in line with that reported in Germany [63], where $83.5 \%$ of greening projects are extensive systems that offer a 
more cost-effective solution over intensive systems. Extensive green roofs are relatively maintenance-free and will readily survive European climates.

This result encourages planners to consider increasing the greening intensity and, with it, lowering thermal transmittance to $0.15 \mathrm{~W} / \mathrm{m}^{2} \mathrm{~K}$, changing from an extensive roof $\left(0.42 \mathrm{~W} / \mathrm{m}^{2} \mathrm{~K}\right)$ to a semi-intensive $\left(0.27 \mathrm{~W} / \mathrm{m}^{2} \mathrm{~K}\right)$ [40].

Moreover, noise will be attenuated. Speech levels and reverberation time at $500 \mathrm{~Hz}$ might decrease by $9.3 \mathrm{~dB}$ and $81 \%$, respectively [58].

Additionally, depending on the vegetation the sequestered aboveground carbon can increase to up to $175 \mathrm{~g} \mathrm{C} \cdot \mathrm{m}^{-2}$ per two growing seasons, from $64 \mathrm{~g} \mathrm{C} \cdot \mathrm{m}^{-2}$ (Sedum acre) to $239 \mathrm{~g} \mathrm{C} \cdot \mathrm{m}^{-2}$ (Sedum album) [35]. Asia and Oceania had the highest and similar runoff water management, due to the intensity. The lowest and most similar stormwater retention was found in Africa, Europe, and America, where stormwater runoff management can be improved by increasing the media depth of greening $[47,48,51]$ while leached pollutants could be also improved [9].

The increase of the media depth, from extensive (60\% runoff mitigation) to intensive $(100 \%)$, might lead to an increase of the runoff mitigation of $40 \%$ [52] along with an improvement in reduction of the air temperature by $7^{\circ} \mathrm{C}$ for each $16 \mathrm{~cm}$ of depth of the substrate added.

The best slope to manage runoff water was found in Africa. The lowest stormwater retention was found in Oceania, where Williams et al. [65] pointed out a poor development of green roof technology.

The largest greening interventions were found in Asia, which were significantly similar to Oceania and Africa and significantly different to Europe and America (Table 4). America showed greening of small and single-family homes. Policymakers can decide to undertake large, strategically located GRW in cities or promote a large number of singlefamily or individual greenings. Further research involving cost-benefit analyses could help managers optimise decisions. Roof and walls vegetated can decrease the air temperature $6.2{ }^{\circ} \mathrm{C}$ higher than only walls vegetated (in Riyadh, 11.3 and $5.1{ }^{\circ} \mathrm{C}$, respectively [20]). Moreover, it is probed that coverage ratio of $70 \%$ and $2.25 \mathrm{~mm}$ total leaf depth could lead to an $80 \%$ temperature reduction [27].

Table 4. Mean \pm SD of climate changes mitigation indicators ANOVA, DMS post hoc test of difference among continents. Different letters across the same variable denote a statistical difference between continents ( $p$-value $<0.05$ ).

\begin{tabular}{|c|c|c|c|c|c|c|c|}
\hline Greening & Africa & America & Asia & Europe & Oceania & F & $p$-Value \\
\hline \multicolumn{8}{|c|}{ Exposure indicators } \\
\hline Location & $5.00 \pm 1.41 \mathrm{abc}$ & $5.69 \pm 2.06 \mathrm{a}$ & $5.69 \pm 2.03 a$ & $5.36 \pm 2.00 \mathrm{~b}$ & $4.44 \pm 1.62 \mathrm{c}$ & 2.703 & 0.029 \\
\hline Population & $1.00 \pm 0.00 \mathrm{a}$ & $1.32 \pm 0.81 \mathrm{a}$ & $3.14 \pm 2.40 \mathrm{~b}$ & $1.39 \pm 0.94 \mathrm{a}$ & $1.44 \pm 0.78 \mathrm{a}$ & 62.601 & 0.000 \\
\hline $\begin{array}{c}\text { Climatic exposure } \\
\text { UHI }\end{array}$ & $6.00 \pm 0.00 \mathrm{ac}$ & $5.63 \pm 0.72 \mathrm{a}$ & $4.52 \pm 1.58 b$ & $5.91 \pm 0.36 c$ & $5.68 \pm 0.94 \mathrm{ac}$ & 47.675 & 0.000 \\
\hline $\begin{array}{l}\text { Climatic exposure } \\
\text { stormwater runoff } \\
\text { management }\end{array}$ & $9.50 \pm 0.00 \mathrm{a}$ & $7.84 \pm 1.76 \mathrm{a}$ & $7.70 \pm 1.45 \mathrm{a}$ & $6.49 \pm 0.86 b$ & $7.30 \pm 1.44 \mathrm{~b}$ & 31.383 & 0.000 \\
\hline Year-owner & $7.00 \pm 1.41 \mathrm{abcd}$ & $5.85 \pm 2.23 \mathrm{a}$ & $6.76 \pm 2.54 b$ & $4.85 \pm 2.32 \mathrm{c}$ & $8.00 \pm 1.94 \mathrm{~d}$ & 17.174 & 0.000 \\
\hline \multicolumn{8}{|c|}{ Design indicators } \\
\hline $\begin{array}{c}\text { Intensive/extensive } \\
\text { thermal } \\
\text { transmittance }\end{array}$ & $6.00 \pm 0.00 \mathrm{abc}$ & $6.71 \pm 1.95 a$ & $7.33 \pm 3.02 b$ & $6.70 \pm 2.90 \mathrm{a}$ & $4.42 \pm 2.64 \mathrm{c}$ & 6.641 & 0.000 \\
\hline $\begin{array}{l}\text { Intensive/extensive } \\
\text { runoff water } \\
\text { management }\end{array}$ & $3.80 \pm 0.00 \mathrm{a}$ & $5.10 \pm 2.17 \mathrm{a}$ & $6.99 \pm 2.32 b$ & $5.32 \pm 2.58 \mathrm{a}$ & $7.24 \pm 3.17 b$ & 16.014 & 0.000 \\
\hline Greened extension & $1.00 \pm 0.00 \mathrm{abc}$ & $1.04 \pm 0.32 \mathrm{a}$ & $1.65 \pm 1.75 b$ & $1.17 \pm 0.83 c$ & $1.09 \pm 0.61 \mathrm{~b}$ & 23.587 & 0.000 \\
\hline $\begin{array}{l}\text { Slope runoff water } \\
\text { management }\end{array}$ & $9.00 \pm 0.00 \mathrm{abc}$ & $8.42 \pm 2.29 \mathrm{a}$ & $7.08 \pm 4.07 \mathrm{~b}$ & $7.93 \pm 2.87 \mathrm{c}$ & $4.67 \pm 4.39 \mathrm{~d}$ & 15.699 & 0.000 \\
\hline
\end{tabular}

This study provides useful information for planners for decisions and policy makers about the design and exposure of GRWs and mitigation strategies. The findings can enhance the process of creating labels, such as LEED or BREEAM, by incorporating GRW measures 
of exposure and design in order to mitigate urban environmental and climate change. GRW planning requires collaborative efforts of architects, engineers, horticulturists, contractors, and urban planners [66] in order to efficiently mitigate urban environmental and climate change. In this sense, the European Union recommends these ecosystem-based approaches that harness the adaptive forces of nature and are among the most widely applicable, economically viable, and effective tools to combat the impacts of climate change [61].

Our study approach has given rise to several limitations that restrict the scope of generalisations. First, a convenience sampling method was used. Second, we considered similar climatic conditions in the city when climate conditions can change in the city. For this reason, it is concluded that further location specific studies are necessary to efficiently develop GRWs to better mitigate urban environmental and climate change along with more long time measurements [19]. Additionally, protocols of measurement are needed to make comparisons. Specific and separate analysis of green roof and wall designs are required in future research. Third, more studies are needed into costs and benefits and citizen preferences [65] in order to the best design and exposure to mitigate urban environmental and climate change. Moreover, mitigation effects can be potentiated or reduced by other environmental, climatic, social, and economic means that need to be detected [48]. Despite the above considerations, this paper represents a first approach to design and exposure of GRW projects in order to mitigate environmental and urban climate change.

\section{Conclusions}

This study found green roofs and walls of varied effectiveness in ameliorating climate extremes present in host continents.

Results show that the green roofs and walls type of design can ameliorate climate change mitigation. In the UHI reduction, the design of a walls and roof greening compared with a green wall design can decrease the air temperature additionally in $6.2^{\circ} \mathrm{C}$. A semi-intensive roof design can additionally lower the thermal resistance of the building $0.15 \mathrm{~W} / \mathrm{m}^{2} \mathrm{~K}$ with respect to extensive greening. In the greenhouse effect reduction, the sequestered aboveground carbon per two growing seasons in a roof with Sedum acre is $175 \mathrm{~g} \mathrm{C} \cdot \mathrm{m}^{-2}$ greater than in a roof with Sedum album. A green roof and wall with one square meter more of albedo surface can eliminate $38.0 \mathrm{~kg}$ more of $\mathrm{CO}_{2}$ eq. In stormwater runoff management, the green roofs designed in arid climates retain 15.3\% more stormwater than green roofs in continental climates. An intensive green roof mitigates $40 \%$ more runoff than an extensive one. A low-growing vegetation roof attenuates the speech levels and reverberation time at $500 \mathrm{~Hz}$ by $9.3 \mathrm{~dB}$ and $81 \%$, respectively.

Designers and urban planners should focus on temperature attenuation and noise reduction possibilities for the location of greening in cities via green roof and wall interventions. In this sense, results encourage urban planners to consider locations in order to better mitigate UHI and reduce noise in narrow streets. Moreover, the exposure analysis challenges city planners to incorporate greening projects as cities grow.

The design of intensive, all-green projects is recommended for better mitigation of UHI, while intensive designs with proper slope can improve runoff water management.

With respect to continents, Asian planners should focus on the exposure of green roofs and walls to attenuate temperatures of hotter, dryer cities bringing temperatures down to more human-friendly levels. Results encourage greening in most populated cities located in Africa and Asia due to the expectations of population growth. In Europe and America, green roof and wall designers should focus on better runoff water management by increasing the media depth of greening and better insulating older buildings. America and Europe showed less energy consumption reduction due to greening with the highest thermal transmittance. Recommendations are made based on the study to concentrate certain designs to have greater impact on priority climate challenges, whether UHI or stormwater related. 
Author Contributions: Conceptualisation, B.U.; methodology, F.B. and B.U.; software, F.B.; validation, B.U.; data curation, F.B.; writing-original draft preparation, F.B. and B.U.; writing-review and editing, F.B.; supervision, B.U. All authors have read and agreed to the published version of the manuscript.

Funding: This research received no external funding.

Informed Consent Statement: Not applicable.

Data Availability Statement: Not applicable.

Conflicts of Interest: The authors declare no conflict of interest.

\section{References}

1. Nastran, M.; Kobal, M.; Eler, K. Urban heat islands in relation to green land use in European cities. Urban For. Urban Green. 2019, 37, 33-41. [CrossRef]

2. Loh, S. Living walls-Way to green the built environment. BEDP Environ. Des. Guide 2008, 1, 1-7.

3. Hewitt, N.; Ashworth, K.; MacKenzie, R. Using green infrastructure to improve urban air quality (GI4AQ). Ambio 2020, 49, 62-73. [CrossRef]

4. Kim, J.M.; Hong, T.H.; Koo, C.W. Economic and Environmental Evaluation Model for Selecting the Optimum Design of Green Roof Systems in Elementary Schools. Environ. Sci. Technol. 2012, 46, 8475-8483. [CrossRef]

5. Qin, X.; Wu, X.; Chiew, Y.M.; Li, Y. A Green Roof Test Bed for Stormwater Management and Reduction of Urban Heat Island Effect in Singapore. Br. J. Environ. Clim. Chang. 2013, 2, 410-420. [CrossRef] [PubMed]

6. Lopez, G.; Perez Souza, A.; Lucas, L.C. Urban green spaces and the influence on vehicular traffic noise control. Ambient. Construido 2018, 18, 161-175. [CrossRef]

7. Castleton, H.F.; Stovin, V.; Beck, S.B.M.; Davison, J.B. Green roofs; building energy savings and the potential for retrofit. Energy Build. 2010, 42, 1582-1591. [CrossRef]

8. Berardi, U.; Hoseini, A.H. State-of-the-art analysis of the environmental benefits of green roofs. Appl. Energy 2014, 115, 411-428. [CrossRef]

9. Akther, M.; He, J.; Chu, A.; Huang, J.; van Duin, B. A Review of Green Roof Applications for Managing Urban Stormwater in Different Climatic Zones. Sustainability 2018, 10, 2864. [CrossRef]

10. Bates, A.J.; Sadler, J.P.; Mackay, R. Vegetation development over four years on two green roofs in the UK. Urban For. Urban Green. 2013, 12, 98-108. [CrossRef]

11. Eumorfopoulou, E.; Kotoleon, K. Experimental approach to the contribution of plant-covered walls to the thermal behaviour of building envelopes. Build. Environ. 2009, 44, 1024-1038. [CrossRef]

12. Giridharan, R.; Kolokotroni, M. Urban heat island intensity in London: An investigation of the impact of physical characteristics on changes in outdoor air temperature during summer. Sol. Energy 2009, 82, 986-998.

13. Weng, Q.; Lu, D.; Schubring, J. Estimation of land surface temperature-vegetation abundance relationship for urban heat island studies. Remote Sens. Environ. 2004, 89, 467-483. [CrossRef]

14. Kontoleon, K.; Eumorfopoulou, E. The effect of the orientation and proportion of a plant-covered wall layer on the thermal performance of a building zone. Build. Environ. 2010, 45, 1287-1303. [CrossRef]

15. Wong, N.H.; Tan, A.Y.K.; Chen, Y.; Sekar, K.; Tan, P.Y.; Chan, D.; Chiang, K.; Wong, N.C. Thermal evaluation on vertical greenery systems for building walls. Build. Environ. 2010, 45, 663-672. [CrossRef]

16. Lundholm, J.; MacIvor, J.S.; MacDougall, Z.; Ranalli, M. Plant Species and Functional Group Combinations Affect Green Roof Ecosystem Functions. PLoS ONE 2010, 5, e9677. [CrossRef] [PubMed]

17. Jim, C.Y.; Peng, L.L.H. Substrate moisture effect on water balance and thermal regime of a tropical extensive green roof. Ecol. Eng. 2012, 47, 9-23. [CrossRef]

18. Ouldboukhitine, S.E.; Belarbi, R.; Djedjig, R. Characterization of green roof components: Measurements of thermal and hydrological properties. Build. Environ. 2012, 56, 78-85. [CrossRef]

19. Köhler, M.; Kaiser, D. Evidence of the Climate Mitigation Effect of Green Roofs-A 20-Year Weather Study on an Extensive Green Roof (EGR) in Northeast Germany. Buildings 2019, 9, 157.

20. Alexandri, E.; Jones, P. Temperature decreases in an urban canyon due to green walls and greenroofs in diverse climates. Build. Environ. 2008, 43, 480-493. [CrossRef]

21. Holm, D. Thermal improvement by means of leaf cover on external walls-A simulation model. Energy Build. 1989, 14, 19-30. [CrossRef]

22. Varvara, M.S.; Köhler, M.; Voevod, M.; Dirja, M. Study Regarding Temperature Differences between a Traditional Roof and Green Roof. Bulletin of University of Agricultural Sciences and Veterinary Medicine Cluj-Napoca. Horticulture 2015, 72, 433-437.

23. Alonso, J.; Chanampa, M.; Vidal, P.; Guerra, R.; Neila, F.J.; Bedoya, C. Systems that enhance the environmental quality in cities. Cuad. Investig. Urban. CICR 2009, 67, 49-67. 
24. Bass, B.; Krayenh, S.; Martilli, A. The impact of green roofs on Toronto's urban heat island. In Mitigating the urban heat island with Green Roof Infrastructure, Proceedings of the Urban Heat Island Summit, Toronto, ON, Canada, 17-20 October 2002; The Cardinal Group Inc.: Toronto, ON, Canada, 2002.

25. Susca, T.; Gaffin, S.R.; Dell'Osso, G.R. Positive effects of vegetation: Urban heat island and green roofs. Env. Pollut. 2011, 159, 2119-2126. [CrossRef]

26. Gorbachevskaya, O.; Schreiter, H. Contribution of extensive building naturation to air quality improvement. In Proceedings of the International Scientific Conference Local Air Quality and Its Interactions with Vegetation, Antwerpen, Belgium, 21-22 January 2010.

27. Fang, C.F. Evaluating the thermal reduction effect of plant layers on rooftops. Energy Build. 2008, 40, 1048-1052. [CrossRef]

28. Takebayashi, H.; Moriyama, M. Surface heat budget on green roof and high reflection roof for mitigation of urban heat island. Build. Environ. 2007, 42, 2971-2979. [CrossRef]

29. Reidy, C. Roof Gardens: Looking Good, Saving Money; The Boston Globe: Boston, MA, USA, 2004.

30. Neila, F.J.; Bedoya, C.; Acha, C.; Olivieri, F.; Barbero, M. Green roofs of third generation: A new building material. Inf. Constr. 2008, 60, 15-24. [CrossRef]

31. Bozsaky, D. The historical development of thermal insulation materials. Period. Polytech. Archit. 2011, 41, 49-56. [CrossRef]

32. European Parliament and of the Council. Directive 2010/31/EU of the European Parliament and of the Council of 19 May 2010 on the Energy Performance of Buildings. Available online: https: / / eur-lex.europa.eu/legal-content/EN/TXT/?uri=celex\%3A3 2010L0031 (accessed on 17 February 2021).

33. Ratcliffe, M.; Day, T. Improving Office Staff Productivity While Reducing Carbon Dioxide Emissions. Available online: http:/ / seedengr.com/Improving\%20Office\%20Staff\%20Productivity\%20while\%20Reducing\%20Carbon\%20Dioxide\%20 Emissions.pdf (accessed on 20 December 2020).

34. Rowe, D.B. Green roofs as a means of pollution abatement. Environ. Pollut. 2011, 159, 2100-2110. [CrossRef]

35. Getter, K.L.; Rowe, D.B.; Robertson, G.P.; Cregg, B.M.; Andersen, J.A. Carbon Sequestration Potential of Extensive Green Roofs. Environ. Sci. Technol. 2009, 43, 7564-7570. [CrossRef]

36. Tabares-Velasco, P.C.; Zhao, M.J.; Peterson, N.; Srebric, J.; Berghage, R. Validation of predictive heat and mass transfer green roof model with extensive green roof field data. Ecol. Eng. 2012, 47, 165-173. [CrossRef]

37. Santamouris, M. Cooling the cities-A review of reflective and green roof mitigation technologies to fight heat island and improve comfort in urban environments. Solar Energy 2012, 103, 682-703. [CrossRef]

38. Del Barrio, E.P. Analysis of the green roofs cooling potential in buildings. Energy Build. 1998, 27, 179-193. [CrossRef]

39. Liu, K.; Minor, J. Performance evaluation of an extensive green roof. In Proceedings of the Third Annual Greening Rooftops for Sustainable Communities Conference, Awards and Trade Show, Washington, DC, USA, 4-6 May 2005.

40. Wong, N.H.; Cheong, D.K.W.; Yan, H.; Soh, J.; Ong, C.L.; Sia, A. The effects of rooftop garden on energy consumption of a commercial building in Singapore. Energy Build. 2003, 35, 353-364. [CrossRef]

41. Alcazar, S.; Bass, B. Energy performance of green roofs in a multi storey residential building in Madrid. In Greening Rooftops for Sustainable Communities; U.S. Department of Energy Office of Scientific and Technical Information: Washington, DC, USA, 2005.

42. Lazzarin, R.M.; Castellotti, F.; Busato, F. Experimental measurements and numerical modeling of a green roof. Energy Build. 2005, 37, 1260-1267. [CrossRef]

43. Alsup, S.; Ebbs, S.; Retzlaff, W. The exchangeability and leachability of metals from select green roof growth substrates. Urban Ecosyst. 2010, 13, 91-111. [CrossRef]

44. Vijayaraghavan, K.; Joshi, U.M.; Balasubramanian, R. A field study to evaluate runoff quality from green roofs. Water Res. 2012, 46, 1337-1345. [CrossRef]

45. Berndtsson, J.C. Green roof performance towards management of runoff water quantity and quality: A review. Ecol. Eng. 2010, 36, 351-360. [CrossRef]

46. Roesner, L.A. Urban runoff pollution-Summary thoughts-The state of practice today and for the 21st century. Water Sci. Technol. 1999, 39, 353-360. [CrossRef]

47. Vanwoert, N.D.; Rowe, D.B.; Andresen, J.A.; Rugh, C.L.; Fernandez, R.T.; Xiao, L. Green roof stormwater retention: Effects of roof surface, slope, and media depth. J. Environ. Qual. 2005, 34, 1036-1044. [CrossRef]

48. Mentens, J.; Raes, D.; Hermy, M. Green roofs as a tool for solving the rainwater runoff problem in the urbanised 21st century? Landsc. Urban Plan. 2006, 77, 217-226. [CrossRef]

49. Bengtsson, L.; Grahn, L.; Olsson, J. Hydrological function of a thin extensive green roof in southern Sweden. Hydrol. Res. 2005, 36, 259-268. [CrossRef]

50. Villarreal, E.L.; Bengtsson, L. Response of a Sedum green-roof to individual rain events. Ecol. Eng. 2005, 25, 1-7. [CrossRef]

51. Monterusso, M.A.; Rowe, D.B.; Rugh, C.L.; Russell, D.K. Runoff water quantity and quality from green roof systems. Acta Hortic. 2004, 639, 369-376. [CrossRef]

52. Dunnett, N.; Nagase, A.; Booth, R.; Grime, P. Influence of vegetation composition on runoff in two simulated green roof experiments. Urban Ecosyst. 2008, 11, 385-398. [CrossRef]

53. Mickovski, S.B.; Buss, K.; McKenzie, B.M.; Sokmener, B. Laboratory study on the potential use of recycled inert construction waste material in the substrate mix for extensive green roofs. Ecol. Eng. 2013, 61, 706-714. [CrossRef] 
54. Getter, K.L.; Rowe, D.B.; Andersen, J.A. Quantifying the effect of slope on extensive green roof stormwater retention. Ecol. Eng. 2007, 31, 225-231. [CrossRef]

55. Urbano, B. Greening, an urbanization coping mechanism. Rev. Chapingo Ser. Cienc. For. Ambient. 2013, 19, $225-235$.

56. European Commission. Science for Environment Policy: Urban Greening Reduces Noise Pollution, SCU; The University of the West of England: Bristol, UK, 2003.

57. Van Renterghem, T.; Hornikx, M.; Forssen, J.; Botteldooren, D. The potential of building envelope greening to achieve quietness. Build. Environ. 2013, 61, 34-44. [CrossRef]

58. Yang, H.S.; Kang, J.; Choi, M.S. Acoustic effects of green roof systems on a low-profiled structure at street level. Build. Environ. 2012, 50, 44-55. [CrossRef]

59. Threlfall, C.; Mata, L.; Mackie, J.A.; Hahs, A.K.; Stork, N.; Williams, N.S.G.; Livesley, S.J. Increasing biodiversity in urban green spaces through simple vegetation interventions. J. Appl. Ecol. 2017, 54, 1874-1883. [CrossRef]

60. FAO United Nations Food and Agriculture Organization. Greener Cities: Cities of Despair- or Opportunity? United Nations Food and Agriculture Organization: Rome, Italy, 2019.

61. EU. Communication from the Commission to the European Parliament, the Council, the European Economic and Social Committee and the Committee of the Regions Green Infrastructure (GI)_Enhancing Europe's Natural Capital; European Commission: Brussels, Switzerland, 2013; Available online: https:/ / eur-lex.europa.eu/legal-content/EN/TXT/?uri=celex\%3A52013DC0249 (accessed on 17 February 2021).

62. Kottek, M.; Grieser, J.; Beck, C.; Rudolf, B.; Rubel, F. World map of the Köppen-Geiger climate classification updated. Meteorol. Z. 2006, 15, 259-263. [CrossRef]

63. BuGG. Marktreport Gebäudegrün 2020, Dach-, Fassaden- und Innenraumbegrünung Deutschland; Bundesverband GebäudeGrün e.V. (BuGG): Berlin, Germany, 2020.

64. Livingroofs. Available online: http:/ / www.livingroofs.org/livingpages/auditlondon.html (accessed on 18 December 2020).

65. Williams, N.S.G.; Rayner, J.P.; Raynor, K.J. Green roofs for a wide brown land: Opportunities and barriers for rooftop greening in Australia. Urban For. Urban Green. 2010, 9, 245-251. [CrossRef]

66. Parizotto, S.; Lamberts, R. Investigation of green roof thermal performance in temperate climate: A case study of an experimental building in Florianópolis city. Southern Brazil. Energy Build. 2011, 43, 1712-1722. [CrossRef] 